\title{
REVIEW
}

\section{Osteosarcoma Overview}

Brock A. Lindsey $\cdot$ Justin E. Markel $\cdot$ Eugenie S. Kleinerman

Received: September 30, 2016 / Published online: December 8, 2016

(C) The Author(s) 2016. This article is published with open access at Springerlink.com

\section{ABSTRACT}

Osteosarcoma (OS) is the most common primary malignancy of bone and patients with metastatic disease or recurrences continue to have very poor outcomes. Unfortunately, little prognostic improvement has been generated from the last 20 years of research and a new perspective is warranted. OS is extremely heterogeneous in both its origins and manifestations. Although multiple associations have been made between the development of osteosarcoma and race, gender, age, various genomic alterations, and exposure situations among others, the etiology remains unclear and controversial. Noninvasive diagnostic methods include serum markers like alkaline phosphatase and a growing variety of imaging techniques

Enhanced content To view enhanced content for this article, go to http://www.medengine.com/Redeem/ 4527F0605329F539.

B. A. Lindsey $(\bowtie) \cdot$ J. E. Markel

Department of Orthopaedics, West Virginia

University, Morgantown, WV, USA

e-mail: blindsey@hsc.wvu.edu

E. S. Kleinerman

Division of Pediatrics, MD Anderson Cancer Center,

Houston, TX, USA including X-ray, computed tomography, magnetic resonance imaging, and positron emission as well as combinations thereof. Still, biopsy and microscopic examination are required to confirm the diagnosis and carry additional prognostic implications such as subtype classification and histological response to neoadjuvant chemotherapy. The current standard of care combines surgical and chemotherapeutic techniques, with a multitude of experimental biologics and small molecules currently in development and some in clinical trial phases. In this review, in addition to summarizing the current understanding of OS etiology, diagnostic methods, and the current standard of care, our group describes various experimental therapeutics and provides evidence to encourage a potential paradigm shift toward the introduction of immunomodulation, which may offer a more comprehensive approach to battling cancer pleomorphism.

Keywords: Bone cancer; Bone sarcoma; Metastatic osteosarcoma; Osteosarcoma; Treatment for sarcoma 


\section{INTRODUCTION}

Osteosarcoma (OS) is an osteoid-producing malignancy of mesenchymal origins. This high-grade tumor is the most common primary malignancy of bone and is often fatal in both children and adults. While primary bone cancers represent less than $0.2 \%$ of all cancers [1], according to the National Cancer Institute SEER (Surveillance, Epidemiology, and End Results) program, their frequency has been increasing by $0.3 \%$ per year over the last decade [2]. While OS occurs most frequently in patients between 5 years of age and early adulthood, incidence peaks again in the older ( $>65)$ populations and has been associated with pre-existing Paget's disease and prior radiation therapy [3-7]. Collectively, the metaphysis of the lower long bones, specifically the distal femur and proximal tibia, are the most commonly involved primary sites, with patients over 25 displaying a greater variety of bony locations [3].

Metastatic disease is classified by location as either pulmonary or extrapulmonary and is the major cause of OS-related death [8-10]. While bony metastases are associated with poorer prognoses (with reports of $13 \%$ survival at 5 years [11]), the lung is involved in approximately $80 \%$ of cases [12] and subsequent respiratory compromise is responsible for most of the death toll [13]. Compared with a potential cure rate of over $60 \%$ in patients presenting with nonmetastatic disease [12, 14], those with detectable metastases at the time of diagnosis (approximately 15-20\% [15, 16]) have the poorest overall prognoses [17-22], with reports of 5-year survival rates as low as $19 \%[17,23]$. Moreover, even in the subset of patients free of primary metastases, $40 \%$ will go on to eventually develop a secondary metastasis [12]; in one study, survival rates of patients with nonmetastatic high-grade OS with subsequent metastases were $23 \%$ at 5 years and $0 \%$ at 4 years for pulmonary and bony metastases, respectively [24].

In contrast to distant pulmonary and extrapulmonary metastases, skip lesions (also known as skip metastases or synchronous regional bone metastases) are local and yet potentially more serious metastatic complications. These small, anatomically isolated cancerous foci are distinct from the primary tumor and located either within the same bone or transarticular to it $[25,26]$. Classically, they are associated with extensive metastatic dissemination, robust therapeutic resistance, and particularly poor prognoses [27-29].

Similar to those with metastatic OS, patients with recurrent disease have comparably dismal 5-year post-relapse-overall-survival (PROS) rates [18]. In addition, features such as axial tumor site [30, 31], male sex [30], and advancing age [31] have all shown correlation with inferior patient outcomes. Notably, the pre-operative histologic response to neoadjuvant chemotherapy, as judged by the extent of tumor necrosis, offers some of the most important predictive value regarding overall patient survival [30, 32-34].

\section{Compliance with Ethics Guidelines}

This article is based on previously conducted studies and does not involve any new studies of human or animal subjects performed by any of the authors.

\section{ETIOLOGY AND GENOMICS}

OS etiology is complex and not well understood. The molecular pathogeneses and genetics of OS are vast and extremely 
heterogeneous [35], with discrepancies in the literature regarding its demographic and environmental influences further complicating the story. Most cases are sporadic; however, increased risk has been associated with multiple germline mutation disorders including hereditary retinoblastoma [36, 37], Rothmund-Thomson syndrome [38, 39], Li Fraumeni syndrome [40], and Bloom syndrome [41], among others.

Classically, alterations in the retinoblastoma $(\mathrm{Rb})$ gene have been strongly associated with a predisposition for developing OS [42-44] and loss of heterozygosity has been reported to occur in up in $40-70 \%$ of cases [45-49]. Additionally, altered p53 loci, which have been reported to occur in approximately $10-39 \%$ of cases [49-59], display synergistic tumorigenic properties [50, 60-62]. Whole genome sequencing studies have attempted to elucidate recurrent chromosomal structural patterns, most recently with loci at $6 \mathrm{p} 21.3$ and 2p25.2 displaying potentially genome-wide significance [63, 64]. However, despite these and countless other genetic similarities discovered across cell lines, OS continues rapidly modifying its genotype, thus making potential targeted molecular therapeutics increasingly impractical. To date, no single genetic target has proven therapeutically successful, and this wealth of information has yet to lead to a significant decrease in mortality [35].

As per the central dogma, this genotypic heterogeneity has translated into a wide variety of macromolecular biomarker expression profiles with potentially useful clinical implications. Indeed, phenotypic trends have been found and characterized across various OS cell lines. Multiple studies have identified characteristic protein and mRNA expression profiles showcasing anomalous levels of ErbB-2
[65, 66], cathepsin D [67], FBXW7 [68], miR-421 [69], and HMGB1 [70], among others. It has also been suggested that matrix-Gla protein expression may play a role in facilitating tumor spread to the lungs [71]. However, as of yet, the true diagnostic, etiologic, and clinical significance of these biomarkers is ongoing and controversial.

Apart from genetic mutations and expression profiles, studies have also discovered correlations between poor prognosis (or increased incidence) and various demographics such as male gender [72], old age [73, 74], height [75], and African American descent [76]. Others have suggested an association between bone growth and incidence rates [75, 77-80], but the relative strength and importance of this relationship have been challenged [81]. Environmental factors that have been associated with increased risk of future OS development include exposure to radiation [6, 7], teriparatide usage [82], and consumption of fluorinated drinking water during childhood [83, 84]; however, more recent studies have disputed the latter two relationships [85-88].

\section{DIAGNOSIS AND PATHOLOGY}

Due to the complex nature of primary bone malignancies, diagnosis of OS is best accomplished via a comprehensive multidisciplinary approach [89]. Often, the first sign of potential bone malignancy is intermittent pain around the affected area with or without a palpable mass [90]. When involving areas around the knee joint, pain exacerbated by weight bearing may manifest as a limp; occasionally, patients will present with a recent bout of bone trauma [91]. As previously mentioned, any older adult with a history of Paget's disease has an increased risk of 
developing OS, most notably of the pelvis [92], and this transformation is associated with a poor prognosis [93].

Various serum markers have been investigated for their utility in diagnosing and tracking progression and recurrence. Alkaline phosphatase (ALP) and lactose dehydrogenase (LDH) are useful serum biomarkers, with ALP carrying the most diagnostic value in OS $[94,95]$. ALP has also been shown to correlate positively with tumor volume, which carries additional useful prognostic implications [94-96]. LDH has also been shown to correlate with tumor volume; however, the correlation is weaker than for ALP and is mainly a result of nonspecific metabolic demand [95]. If disease is suspected, the first step is to gather plain radiographs of the involved bone and adjacent joint. Any abnormal films then warrant further radiological investigation of soft tissue involvement and possible primary lung metastasis via magnetic resonance imaging (MRI) and computed tomography (CT), respectively [97]. Bone scintigraphy (BS) is often used in conjunction with CT to identify metastases and the presence or absence of metastatic disease remains one of the most important predictors of patient outcome $[97,98]$. For a more detailed, flow chart-style approach to patient work-up, please refer to the guidelines put forth by the National Comprehensive Cancer Network (NCCN) for bone cancer, Version 2.2017 [99].

Although they have not yet taken the place of BS in OS diagnosis, various experimental test procedures such as positron emission tomography (PET) scans are currently being investigated for their potentially superior ability to diagnose and track the progression of bone cancers. In 2009, Costelloe et al. demonstrated that combined PET/CT could be used to reliably predict the progression-free survival (PFS), overall survival, and extent of tumor necrosis in OS [100]. Studies have also suggested enhanced sensitivity with the use of fludeoxyglucose-( ${ }^{18}$ F-FDG)-PET-CT over BS for detecting metastases [101]. Hyung-Jun Im et al. [102] used a similar technique to show that initial baseline metabolic tumor volume and total lesion glycolysis have independent prognostic value in determining survival in pediatric osteosarcoma populations. Importantly, combined PET/CT scanning has been shown to accurately determine the extent of histological osteonecrosis and may offer a less-invasive alternative to the typical biopsy-requiring Huvos grading system [103], as previously described [104]. Please refer to Table 1 for a list of test properties, including sensitivity, specificity, and a brief note on diagnostic application (as indicated by the study from which those numbers were derived). Note, however, that despite the promising aspects of these non-invasive techniques, a biopsy is always required to confirm the diagnosis [105]. As such, proper disease management mandates tissue collection with the correct identification of the specific histologic subtype [106]. While many subtypes exist and correlate specifically to corresponding chemotherapeutic responses [107], the unifying histological feature is the presence of osteoid-producing malignant cells [105].

Incisional or core needle biopsy is the final step in the diagnostic process [97] and the tumor is staged using the Musculoskeletal Tumor Society staging scheme [108] or the American Joint Commission on Cancer (AJCC) system. In the AJCC system, the tumor is described based on four important factors represented by letters [109]: $\mathrm{T}$ (primary tumor size), $\mathrm{N}$ (spread to regional lymph nodes), $\mathrm{M}$ (metastasis), and G (grade). Each letter is then assigned a particular number (e.g., T1) that 
Table 1 OS serological and radiological test properties with diagnostic applications

\begin{tabular}{|c|c|c|c|}
\hline Test & Sensitivity & Specificity & Application \\
\hline \multirow[t]{2}{*}{ Serum ALP [95] } & 0.78 & 0.94 & Correlation $(r=0.5)$ with tumor volume \\
\hline & & & Most descriptive for osteoblastic subtype \\
\hline \multirow[t]{2}{*}{ Serum LDH $[95]$} & 0.82 & 0.97 & Correlation $(r=0.4)$ with tumor volume \\
\hline & & & Describes tumor metabolic demand \\
\hline Spiral CT $[195]$ & 0.75 & 1.00 & Pulmonary metastases \\
\hline FDG-PET [195] & 0.5 & 0.98 & Pulmonary metastases; confirmation of CT abnormality \\
\hline $\mathrm{PET} / \mathrm{CT}[196]$ & 0.95 & 0.98 & Bony metastases (examination-based analysis) \\
\hline BS [196] & 0.76 & 0.97 & Bony metastases (examination-based analysis) \\
\hline $\mathrm{PET} / \mathrm{CT}+\mathrm{BS}[196]$ & 1.00 & 0.96 & Bony metastases (examination-based analysis) \\
\hline FDG-PET/CT [197] & 0.947 & Not reported & Initial staging or assessment of recurrent disease \\
\hline
\end{tabular}

describes the tumor's pathologic extent (T, N, and $\mathrm{M}$ ) and histological appearance (G). Once assigned its corresponding TxNxMxGx code, the tumor can then be grouped into its corresponding stage, with Stage $1 \mathrm{~A}$ being the most localized and Stage IVB the most invasive. This information can be used to determine prognosis, assess response to therapy, and monitor disease progression [110].

Osteosarcoma subtypes include osteoblastic, chondroblastic, fibroblastic, small cell, telangiectatic, high-grade surface, extra-skeletal, and other lower-grade forms including periosteal and parosteal [111]. Based upon their histological appearances, OS subtypes can be grouped into three categories: high-grade, intermediate-grade, and low-grade. Parosteal OS is a low-grade subtype that is fibroblastic in appearance and limited to the bone surface; however, with time, it may progress to involve deeper structures. For this and other low-grade subtypes, treatment involves surgery alone and carries a favorable prognosis. Periosteal OS is chondroblastic on histology and is the only subtype that falls into the intermediate-grade category. Depending on extent of invasion, treatment for intermediate-grade OS often includes systemic chemotherapy. High-grade OS, which includes the classic osteoblastic subtype, is the fastest-growing and most aggressive group. The majority of OS subtypes fall under this category and include osteoblastic, chondroblastic, fibroblastic, small cell, telangiectatic, high-grade surface, and extra-skeletal. Telangiectatic OS is notable for its profuse vascularity and scant osteoid production, which often complicates tissue biopsy and radiographic identification, respectively [112]. Telangiectatic OS also carries with it an anatomical predilection to the epiphyseal region of the bone. All high-grade OS should be considered micrometastatic at diagnosis and treated with surgery and systemic chemotherapy.

\section{TREATMENT}

The current standard for osteosarcoma treatment employs neoadjuvant chemotherapy, surgery, and then post-operative adjuvant chemotherapy. 
Multiple different chemotherapy regimens containing anywhere from two to seven drugs have been used [97, 113, 114]. The four drugs that have shown consistent activity are cisplatin, doxorubicin, high-dose methotrexate with leucovorin rescue, and isofosfamide with or without etoposide. A recent meta-analysis showed that patients who were treated with three drugs had a superior outcome to those that received two drugs. However, there was no benefit in using four drugs compared to three drugs [115]. Indeed, adding standard or high-dose ifosfamide significantly increased toxicity while having negligible effects on outcome [116, 117], which was recently confirmed by an international trial that showed that there was no benefit in adding high-dose ifosfamide plus etoposide to the cisplatin, doxorubicin, methotrexate combination (MAP) [118]. Therefore, MAP multi-agent chemotherapy is the first-line treatment and the standard of care at the present time. For a more thorough investigation of OS chemotherapeutics, please refer to the meta-analysis conducted in 2011 by Anninga et al. [115].

Neoadjuvant (pre-operative) chemotherapy greatly increases relapse-free survival (RFS) of patients with non-metastatic disease $[119,120]$. Furthermore, it allows for tumor categorization into histological response subgroups, which has significant prognostic and clinical value and provides the opportunity to alter the post-operative treatment strategies [121]. The goal for a positive treatment with neoadjuvant chemotherapy is to achieve at least $90 \%$ necrosis on the surgically resected tumor [121]. If the percent necrosis is below $90 \%$ at resection after neoadjuvant treatment, then the post-resection adjuvant chemotherapy regimen can be altered. However, changing the chemotherapy regimen post-operatively based on response has not been shown to have a positive impact on patient outcome [118]; indeed, another finding from the EURAMOS-1 randomized control trial series has reported increased toxicity and secondary malignancies from intensifying chemotherapy regimens (adding both ifosfamide and etoposide to MAP therapy, i.e., MAPIE) for poor responders [122]. For full treatment guidelines with detailed workup flow charts, please refer to the NCCN guidelines for bone cancer, Version 2.2017 [99].

\section{SURGERY AND RADIATION THERAPY}

Surgical excision usually involves tumor resection with negative margins, as multiple studies have linked positive margins with an increased risk of local recurrence (LR) and inferior survival [123]. Classically, Enneking et al. described four different types of surgical margins: intralesional, marginal, wide, and radical [108]. An intralesional margin, as the name suggests, is obtained when the specimen is taken from within the tumor itself. Although these margins have little therapeutic utility, they are often used for biopsies and have diagnostic purposes. Marginal and wide margins remove the lesion en bloc, with wide leaving a substantial border of normal tissue. This border of normal tissue surrounding the tumor is absolutely paramount in the treatment of OS. Despite these definitions, however, the proper margin to obtain on a case-by-case basis has been continually met with controversy; to date, no general consensus has been born out of the literature. In 2012, a retrospective cohort of 47 patients found no significant difference in LR between groups with close (tumor $<5 \mathrm{~mm}$ from resection margin) and wide (tumor $>5 \mathrm{~mm}$ from resection margin) margins [124]. The following year, Jeon et al. suggested that negative tumor 
margins correlate with significantly lower risks of LR in bone and perineurovascular resection planes while having little influence on LR in soft tissue [125]. Furthermore, there is also evidence to support that the risk of LR is higher in patients treated with closer margins [112]. In either case, when adequate margins cannot be achieved, amputation should be considered [126]. Naturally, limb-salvage is greatly preferred over amputation; over $85 \%$ of patients are candidates for this type of procedure [127-130].

In patients with disseminated disease, the complete resection of pulmonary metastases is vital when possible [131, 132], as lung metastectomy has been shown to significantly prolong survival in this population [133, 134]. Patients with recurrent unresectable metastases usually have poorer prognoses, even when treated aggressively with pre-operative chemotherapy [135]. For recurrent or refractory disease, some studies have suggested that incorporating etoposide into the chemotherapy treatment regimen may be beneficial [136]; however, these data are controversial and associated with severe toxicities [137]. Whenever possible, surgical resection of recurrent disease is first-line over systemic therapy, which is less effective and reserved for unresectable cases [20]. Radiation therapy may also be used to help clear microscopic or minimal residual disease when substantial surgical resection is not possible [138]; however, for a majority of cases, radiation is not used.

\section{NEW THERAPEUTIC APPROACHES}

New effective OS therapies have plateaued over the last several decades; this lack of new treatment strategies is reflected by unchanging survival rates $[3,139]$. As OS cells tend to exhibit extreme genetic pleomorphism, therapeutic attempts to target specific cell receptors and intracellular signaling molecules have not significantly increased survival. In addition, and likely as a result of its pleomorphism, OS cells exhibit strong chemotherapy resistance, most notably in the $15-20 \%$ of patients initially presenting with detectable metastases at the time of diagnosis [15], and who consequently have the poorest prognoses [17-22]. Therefore, MAP adjuvant treatment strategies have had minimal beneficial effects on this subset of patients [140]; as such, a number of alternative therapeutic modalities have been investigated.

Various biologics and small molecules have been used to target cell-surface receptors and downstream signaling pathways involved in OS pathogenesis. For example, as HER2 is often expressed in a subset of OS cell lines and has been associated with poorer prognoses [141], a phase II trial was conducted using trastuzumab to target HER2-positive OS; however, despite minimal drug reactions and additional toxicity, no significant difference in groups was observed [142]. Pappo et al. conducted a similar phase II trial targeting another receptor commonly expressed by malignant cells, IGF-1R [143]; again, clinical responses were underwhelming [144]. The PI3K/mTOR pathway $[145,146]$ and mitogen-activated protein kinases [146, 147] have also recently been recognized as potential targets and their therapeutic significance is currently under investigation.

Over the past few decades, increasing evidence has suggested that platelets and other mesenchymal cells, notably the PDGFR-alpha-R for OS [148], can assist tumor cell pathogenesis [149]. Indeed, Labelle et al. [150] showed that platelet-tumor cell interactions, mediated by activation of transforming growth factor (TGF)-beta/SMAD (small mothers against 
decapentaplegic) and nuclear factor (NF)-kappa-B, could promote metastasis by inducing an epithelial-mesenchymal-like transition. As such, Takagi et al. [151] was able to significantly inhibit platelet-induced OS cell proliferation by blocking Akt-mediated downstream signaling using sunitinib. Likewise, sunitinib has since been shown to reduce tumor burden and lung metastasis in mice [152]; however, the clinical significance of these initial data is yet to be determined.

Elucidating the mechanisms of OS's robust chemoresistance has yielded other potentially promising therapeutic targets. Recently, it has been shown that HMGB1-induced autophagy contributes to OS chemotherapy resistance [153]; hence, this and other chemoresistance-promoting pathways provide the means for new therapeutic approaches and their inhibitors deserve further investigation. Other potential therapeutics currently under investigation include zoledronic acid [154] and even the natural phenolic compound, curcumin [155].

Due to the vast heterogeneity of OS molecular profiles [35-40, 63, 64], the future of OS treatment may be moving away from targeted anti-oncogenic paradigms and toward more generalized immunomodulatory/ immunoeditory approaches [156]. Cancer immunotherapy, although still in its infancy, attempts to enhance tumor immunogenicity and stimulate tumorocidal activity, thereby reallocating the burden of disease clearance back to the patient's own body. Nonspecific immunogens, cytokines, adoptive T-cells, vaccines, oncolytic virotherapies, and checkpoint blockades have all shown potential therapeutic promise [157]. If deemed clinically advantageous, these new immunotherapeutics will likely be administered as adjuvants and integrated into the current standard of care.
Muramyl tripeptide (MTP), which has been shown to activate NF- $\kappa B$ [158] and increase circulating levels of TNF alpha and interleukin-6 (IL-6) in patients with OS [159], can be packaged within liposomes [160] and injected [161, 162]. This liposomal product (Mifamurtide) allows for particle ingestion by monocytes and macrophages and the subsequent activation of their cytotoxic function against tumor cells [163]. Tumor-associated macrophages, although mostly thought of as being pro-tumorigenic [164], have been found to play a potentially significant role in preventing metastasis in high-grade OS [165]. In patients with no clinically detectable metastases and in those with resectable disease, the addition of Mifamurtide to multi-agent chemotherapy has been shown to significantly increase event-free survival (EFS) and overall survival with a $29 \%$ reduction in the mortality rate at 8 years [166]. The addition of Mifamurtide also improved the outcomes of patients who presented with metastases at the time of diagnosis [167]. A therapeutic synergism of MTP with zoledronic acid on primary tumor progression has also been suggested [168].

There have also been attempts to target immunotherapy directly to the lungs via the use of aerosols, which have the potential benefit of lowering systemic toxicity by being delivered directly to the site of action [169]. OS relapse most commonly occurs as pulmonary metastasis [105], with patient survival often being below $30 \%[170,171]$ and as low as $14 \%$ [20] in these cases. Granulocyte-macrophage colony stimulating factor (GM-CSF), a molecule with multiple roles in immune regulation and phagocyte maturation [172], was recently used in a phase II trial of post-relapse OS patients to investigate its effect on disease-free survival (DFS). However, despite the ability to reach 
adequately high doses with minimal side effects, no significant improvement in survival was seen [173]. While these results are disappointing, they may indicate that the immunomodulatory effects of GM-CSF alone were not enough to influence a tumorocidal environment. Unfortunately, there was no investigation of whether GM-CSF treatment resulted in any biologic effect on the lung tumor nodules. Therefore, it is hard to assess whether this therapy resulted in the desired effect in terms of activating an immune response in the lung. Thus, the possibility remains that the lack of therapeutic effect was secondary to the inability of GM-CSF to stimulate an immune response in the lung. Indeed, there is growing evidence to support that the chemical profile of tumor microenvironments comprises an astonishingly complex constellation of signaling molecules in various distributions $[174,175]$ and it is highly possible that further manipulation may be necessary to achieve an effective tumorocidal environment [176]. As such, Zeidner et al. and Wang et al. have shown that combinations of GM-CSF with interferon (IFN) and IL-12 therapy improved outcomes for chronic myeloid leukemia patients [177] and increased antitumor effects against murine hepatocellular carcinoma [178], respectively. Another more recent immunotherapeutic attempt at combating OS pulmonary metastasis with combination immunotherapy included aerosol IL-2 with adjuvant natural killer (NK) cell infusions, which has shown enhanced efficacy compared to IL-2 or NK cell infusions alone [179]. Other cytokines, including IL-15 and IL-12, have been shown to increase natural killer cell-mediated lysis of chemotherapy-resistant OS cells [180] and suppress pulmonary metastasis formation [181], respectively.
IFN immunotherapy has also shown promise in the treatment of OS. IFN- $\alpha$, while initially recognized for its ability to inhibit viral replication, is now used in the treatment of a variety of different solid and hematological cancers [182]. In OS, it has been shown to suppress tumor invasion as well as enhance the cytotoxic effects of cisplatin [183]. In 2015, Bielack et al. conducted an international randomized, controlled trial comparing the efficacy of MAP therapy alone versus MAP plus pegylated interferon alpha-2b in 2260 registered patients; however, the results were complicated by insufficient patient adherence and no statistical difference in outcome was found [184]. In 2015, Gao et al. revealed that IFN-lambda1, a relatively new member of the interferon family [185], inhibits the invasive properties of MG-63 human osteosarcoma cell lines in vitro [186]. Another in vitro study showed that INF-gamma can enhance the ability of $\gamma \delta \mathrm{T}$ cells to target and kill HOS and U2OS OS cell lines [187].

As it is now widely accepted that tumors often promote suppression of the immune system in order to facilitate their pathogenesis [188], many immunotherapies have shown promise by targeting immunoregulatory cell-surface markers. Programmed death ligand 1 (PD-L1) and cytotoxic T-lymphocyte-associated protein 4 (CTLA-4) are surface receptors involved in down-regulating the cytotoxic $\mathrm{T}$ cell response [189-191] and their blockade has been implicated in the treatment of a variety of cancers [192]. Interestingly, combined blockade of PD-L1 and CTLA-4 has been shown not only to completely eliminate metastatic osteosarcoma in murine models but also to induce immunity to further inoculation $[193,194]$. 


\section{CONCLUSIONS}

Over the past 25 years, altering or intensifying the chemotherapy regimens for newly diagnosed osteosarcoma patients has failed to improve the $65-70 \%$ long-term survival. The only success in improving patient outcomes was the addition of Mifamurtide to the three-drug or four-drug regimen. Combining Mifamurtide with chemotherapy increased long-term survival from 70 to $78 \%$ at 8 years [166] and improved the outcome of patients who presented with metastases at diagnosis [167]. This improvement shows that immunotherapy is effective against this cancer. As OS therapies move forward over the next 5 years, it is likely that both immunostimulation and suppression blockade immunotherapies will play emerging roles. The genetic heterogeneity and morphological adaptability of OS necessitates a more comprehensive treatment approach, as the disease's molecular repertoire is too vast to be treated successfully by targeted therapies alone. Successful treatment will almost certainly require a combination of these different techniques to best achieve an effective tumorocidal environment; the key will lie in recognizing what specific role each immune cell plays and how best to assist its function.

\section{ACKNOWLEDGEMENTS}

No funding or sponsorship was received for this study or publication of this article. All named authors meet the International Committee of Medical Journal Editors (ICMJE) criteria for authorship for this manuscript, take responsibility for the integrity of the work as a whole, and have given final approval for the version to be published.
Disclosures. Brock A. Lindsey, Justin E. Markel, and Eugenie S. Kleinerman have nothing to disclose.

Compliance with Ethics Guidelines. This article is based on previously conducted studies and does not involve any new studies of human or animal subjects performed by any of the authors.

Open Access. This article is distributed under the terms of the Creative Commons Attribution-NonCommercial 4.0 International License (http://creativecommons.org/licenses/ by-nc/4.0/), which permits any noncommercial use, distribution, and reproduction in any medium, provided you give appropriate credit to the original author(s) and the source, provide a link to the Creative Commons license, and indicate if changes were made.

\section{REFERENCES}

1. Biermann JS, Adkins DR, Agulnik M, Benjamin RS, Brigman B, Butrynski JE, Frassica FJ. Bone cancer. J Natl Compr Canc Netw. 2013;11(6):688-723.

2. SEER Stat Fact Sheets: Bone and Joint Cancer. https://seer.cancer.gov/statfacts/html/bones.html.

3. Mirabello L, Troisi RJ, Savage SA. Osteosarcoma incidence and survival rates from 1973 to 2004. Cancer. 2009;115:1531-43. doi:10.1002/cncr. 24121.

4. Dorfman HD, Czerniak B. Bone cancers. Cancer. 1995;75:203-10. doi:10.1002/1097-0142(19950101) 75:1+<203:AID-CNCR2820751308>3.0.CO;2-V.

5. Ottaviani G, Jaffe N. The epidemiology of osteosarcoma. In: Pediatric and adolescent osteosarcoma. US: Springer; 2009. p. 3-13.

6. Le Vu B, De Vathaire F, Shamsaldin A, Hawkins MM, Grimaud E, Hardiman C, Panis X. Radiation dose, chemotherapy and risk of osteosarcoma after solid tumours during childhood. Int $\mathrm{J}$ Cancer. 1998;77(3):370-7. 
7. Arlen M, Higinbotham NL, Huvos AG, Marcove RC, Miller T, Shah IC. Radiation-induced sarcoma of bone. Cancer. 1971;28(5):1087-99.

8. Eccles SA, Welch DR. Metastasis: recent discoveries and novel treatment strategies. Lancet. 2007;369(9574):1742-57.

9. Pradelli E, Karimdjee-Soilihi B, Michiels JF, Ricci JE, Millet MA, Vandenbos F, Kleinerman ES. Antagonism of chemokine receptor CXCR3 inhibits osteosarcoma metastasis to lungs. Int J Cancer. 2009;125(11):2586-94.

10. Hughes DP. Strategies for the targeted delivery of therapeutics for osteosarcoma. Expert Opin Drug Deliv. 2009;6(12):1311-21.

11. Bacci G, Longhi A, Bertoni F, Briccoli A, Versari M, Pignotti E, Picci P. Bone metastases in osteosarcoma patients treated with neoadjuvant or adjuvant chemotherapy. The Rizzoli experience in 52 patients. Acta Orthopaed. 2006;77(6): 938-43.

12. PosthumaDeBoer J, Witlox MA, Kaspers GJL, Van Royen BJ. Molecular alterations as target for therapy in metastatic osteosarcoma: a review of literature. Clin Exp Metastasis. 2011;28(5):493-503.

13. Snyder CL, Saltzman DA, Ferrell KL, Thompson RC, Leonard AS. A new approach to the resection of pulmonary osteosarcoma metastases: results of aggressive metastasectomy. Clin Orthopaed Relat Res. 1991;270:247-53.

14. Bacci G, Ferrari S, Bertoni F, Ruggieri P, Picci P, Longhi A, Campanacci M. Long-term outcome for patients with nonmetastatic osteosarcoma of the extremity treated at the istituto ortopedico rizzoli according to the istituto ortopedico rizzoli/ osteosarcoma-2 protocol: an updated report. J Clin Oncol. 2000;18(24):4016-27.

15. Meyers PA, Heller G, Healey JH, Huvos A, Applewhite A, Sun MING, LaQuaglia M. Osteogenic sarcoma with clinically detectable metastasis at initial presentation. J Clin Oncol. 1993;11(3):449-53.

16. Kaste SC, Pratt CB, Cain AM, Jones-Wallace DJ, Rao $\mathrm{BN}$. Metastases detected at the time of diagnosis of primary pediatric extremity osteosarcoma at diagnosis. Cancer. 1999;86(8):1602-8.

17. Kager L, Zoubek A, Pötschger U, Kastner U, Flege S, Kempf-Bielack B, Jundt G. Primary metastatic osteosarcoma: presentation and outcome of patients treated on neoadjuvant. Cooperative Osteosarcoma Study Group protocols. J Clin Oncol. 2003;21(10):2011-8.
18. Bacci G, Briccoli A, Longhi A, Ferrari S, Mercuri M, Faggioli F, Picci P. Treatment and outcome of recurrent osteosarcoma: experience at Rizzoli in 235 patients initially treated with neoadjuvant chemotherapy. Acta Oncol. 2005;44(7):748-55.

19. Hawkins DS, Arndt CA. Pattern of disease recurrence and prognostic factors in patients with osteosarcoma treated with contemporary chemotherapy. Cancer. 2003;98(11):2447-56.

20. Ferrari S, Briccoli A, Mercuri M, Bertoni F, Picci P, Tienghi A, Bacci G. Postrelapse survival in osteosarcoma of the extremities: prognostic factors for long-term survival. J Clin Oncol. 2003;21(4):710-5.

21. Schaller RT, Haas J, Schaller J, Morgan A, Bleyer A. Improved survival in children with osteosarcoma following resection of pulmonary metastases. J Pediatr Surg. 1982;17(5):546-50.

22. Walters DK, Steinmann P, Langsam B, Schmutz S, Born W, Fuchs B. Identification of potential chemoresistance genes in osteosarcoma. Anticancer Res. 2008;28(2A):673-9.

23. Mialou V, Philip T, Kalifa C, Perol D, Gentet JC, Marec-Berard P, Hartmann O. Metastatic osteosarcoma at diagnosis. Cancer. 2005;104(5):1100-9.

24. Ward WG, Mikaelian K, Dorey F, Mirra JM, Sassoon A, Holmes EC, Eckardt JJ. Pulmonary metastases of stage IIB extremity osteosarcoma and subsequent pulmonary metastases. J Clin Oncol. 1994;12(9):1849-58.

25. Enneking WF, Kagan A. "Skip" metastases in osteosarcoma. Cancer. 1975;36(6):2192-205.

26. Kager L, Zoubek A, Kastner U, Kempf-Bielack B, Potratz J, Kotz R, Jürgens H. Skip metastases in osteosarcoma: experience of the Cooperative Osteosarcoma Study Group. J Clin Oncol. 2006;24(10):1535-41.

27. Leavey PJ, Day MD, Booth T, Maale G. Skip metastasis in osteosarcoma. J Pediatr Hematol Oncol. 2003;25(10):806-8.

28. Sajadi KR, Heck RK, Neel MD, Rao BN, Daw N, Rodriguez-Galindo C, Simon MA. The incidence and prognosis of osteosarcoma skip metastases. Clin Orthop Relat Res. 2004;426:92-6.

29. Malawer MM, Dunham WK. Skip metastases in osteosarcoma: recent experience. J Surg Oncol. 1983;22(4):236-45.

30. Bielack SS, Kempf-Bielack B, Delling G, Exner GU, Flege S, Helmke K, Zoubek A. Prognostic factors in 
high-grade osteosarcoma of the extremities or trunk: an analysis of 1,702 patients treated on neoadjuvant cooperative osteosarcoma study group protocols. J Clin Oncol. 2002;20(3):776-90.

31. Bentzen SM, Poulsen HS, Kaae S, Myhre Jensen O, Johansen H, Mouridsen HT, Arnoldl C. Prognostic factors in osteosarcomas. A regression analysis. Cancer. 1988;62(1):194-202.

32. Raymond AK, Chawla SP, Carrasco CH, Ayala AG, Fanning CV, Grice B, Edeiken J. Osteosarcoma chemotherapy effect: a prognostic factor. In: Seminars in diagnostic pathology, 1987, vol. 4, no. 3, p. 212-36.

33. Davis AM, Bell RS, Goodwin PJ. Prognostic factors in osteosarcoma: a critical review. J Clin Oncol. 1994;12(2):423-31.

34. Hudson M, Jaffe MR, Jaffe N, Ayala A, Raymond AK, Carrasco H, Robertson R. Pediatric osteosarcoma: therapeutic strategies, results, and prognostic factors derived from a 10-year experience. J Clin Oncol. 1990;8(12):1988-97.

35. Martin JW, Squire JA, Zielenska M. The genetics of osteosarcoma. Sarcoma. 2012;2012:627254.

36. Matsunaga E. Hereditary retinoblastoma: host resistance and second primary tumors. J Natl Cancer Inst. 1980;65(1):43-6.

37. Draper GJ, Sanders BM, Kingston JE. Second primary neoplasms in patients with retinoblastoma. Br J Cancer. 1986;53(5):661.

38. Wang LL, Gannavarapu A, Kozinetz CA, Levy ML, Lewis RA, Chintagumpala MM, Lev D. Association between osteosarcoma and deleterious mutations in the RECQL4 gene in Rothmund-Thomson syndrome. J Natl Cancer Inst. 2003;95(9):669-74.

39. Hicks MJ, Roth JR, Kozinetz CA, Wang LL. Clinicopathologic features of osteosarcoma in patients with Rothmund-Thomson syndrome. J Clin Oncol. 2007;25(4):370-5.

40. Porter DE, Holden ST, Steel CM, Cohen BB, Wallace MR, Reid R. A significant proportion of patients with osteosarcoma may belong to Li-Fraumeni cancer families. Bone Joint J. 1992;74(6):883-6.

41. Bloom D. Congenital telangiectatic erythema resembling lupus erythematosus in dwarfs: probably a syndrome entity. AMA Am J Dis Child. 1954;88(6):754-8.

42. Araki N, Uchida A, Kimura T, Yoshikawa H, Aoki Y, Ueda $\mathrm{T}$, Ono $\mathrm{K}$. Involvement of the retinoblastoma gene in primary osteosarcomas and other bone and soft-tissue tumors. Clin Orthop Relat Res. 1991;270:271-7.

43. Belchis DA, Meece CA, Benko FA, Rogan PK, Williams RA, Gocke CD. Loss of heterozygosity and microsatellite instability at the retinoblastoma locus in osteosarcomas. Diagn Mol Pathol. 1996;5(3):214-9.

44. Deshpande A, Hinds PW. The retinoblastoma protein in osteoblast differentiation and osteosarcoma. Curr Mol Med. 2006;6(7):809-17.

45. Wadayama BI, Toguchida J, Shimizu T, Ishizaki K, Sasaki MS, Kotoura Y, Yamamuro T. Mutation spectrum of the retinoblastoma gene in osteosarcomas. Cancer Res. 1994;54(11):3042-8.

46. Toguchida J, Ishizaki K, Sasaki MS, Ikenaga M, Sugimoto M, Kotoura $\mathrm{Y}$, Yamamuro $\mathrm{T}$. Chromosomal reorganization for the expression of recessive mutation of retinoblastoma susceptibility gene in the development of osteosarcoma. Cancer Res. 1988;48(14):3939-43.

47. Feugeas O, Guriec N, Babin-Boilletot A, Marcellin L, Simon P, Babin S, Brunat-Mentigny M. Loss of heterozygosity of the $\mathrm{RB}$ gene is a poor prognostic factor in patients with osteosarcoma. J Clin Oncol. 1996;14(2):467-72.

48. Goto A, Kanda H, Ishikawa $\mathrm{Y}$, Matsumoto S, Kawaguchi N, Machinami R, Kitagawa T. Association of loss of heterozygosity at the p53 locus with chemoresistance in osteosarcomas. Jpn J Cancer Res. 1998;89(5):539-47.

49. Patiño-García A, Piñeiro ES, Díez MZ, Iturriagagoitia LG, Klüssmann FA, Ariznabarreta LS. Genetic and epigenetic alterations of the cell cycle regulators and tumor suppressor genes in pediatric osteosarcomas. J Pediatr Hematol Oncol. 2003;25(5):362-7.

50. Miller CW, Aslo A, Tsay C, Slamon D, Ishizaki K, Toguchida J, Koeffler HP. Frequency and structure of p53 rearrangements in human osteosarcoma. Cancer Res. 1990;50(24):7950-4.

51. Overholtzer M, Rao PH, Favis R, Lu XY, Elowitz MB, Barany F, Levine AJ. The presence of p53 mutations in human osteosarcomas correlates with high levels of genomic instability. Proc Natl Acad Sci. 2003;100(20):11547-52.

52. Miller CW, Aslo A, Won A, Tan M, Lampkin B, Koefflar HP. Alterations of thep53, Rb andMDM2 genes in osteosarcoms. J Cancer Res Clin Oncol. 1996;122(9):559-65.

53. López-Guerrero JA, López-Ginés C, Pellín A, Carda C, Llombart-Bosch A. Deregulation of the G1 to 
S-phase cell cycle checkpoint is involved in the pathogenesis of human osteosarcoma. Diagn Mol Pathol. 2004;13(2):81-91.

54. Pellin A, Boix-Ferrero J, Carpio D, Lopez-Terrada D, Carda C, Navarro S, Llombart-Bosch A. Molecular alterations of the RBI, TP53, and MDM2 genes in primary and xenografted human osteosarcomas. Diagn Mol Pathol. 1997;6(6):333-41.

55. Tsuchiya T, Sekine KI, Hinohara SI, Namiki T, Nobori T, Kaneko Y. Analysis of the p16INK4, p14ARF, p15, TP53, and MDM2 genes and their prognostic implications in osteosarcoma and Ewing sarcoma. Cancer Genet Cytogenet. 2000;120(2):91-8.

56. Gokgoz N, Wunder JS, Mousses S, Eskandarian S, Bell RS, Andrulis IL. Comparison of p53 mutations in patients with localized osteosarcoma and metastatic osteosarcoma. Cancer. 2001;92(8):2181-9.

57. Henriksen J, Aagesen TH, Maelandsmo GM, Lothe RA, Myklebost O, Forus A. Amplification and overexpression of COPS3 in osteosarcomas potentially target TP53 for proteasome-mediated degradation. Oncogene. 2003;22(34):5358-61.

58. Yan T, Wunder JS, Gokgoz N, Gill M, Eskandarian S, Parkes RK, Andrulis IL. COPS3 amplification and clinical outcome in osteosarcoma. Cancer. 2007;109(9):1870-6.

59. Pompetti F, Rizzo P, Simon RM, Freidlin B, Mew DJ, Pass HI, Carbone M. Oncogene alterations in primary, recurrent, and metastatic human bone tumors. J Cell Biochem. 1996;63(1):37-50.

60. Guo W, Wang X, Feng C. P53 gene abnormalities in osteosarcoma. Chin Med J. 1996;109(10):752-5.

61. Walkley CR, Qudsi R, Sankaran VG, Perry JA, Gostissa M, Roth SI, Alt FW. Conditional mouse osteosarcoma, dependent on p53 loss and potentiated by loss of $\mathrm{Rb}$, mimics the human disease. Genes Dev. 2008;22(12):1662-76.

62. Berman SD, Calo E, Landman AS, Danielian PS, Miller ES, West JC, Mukherjee S. Metastatic osteosarcoma induced by inactivation of $\mathrm{Rb}$ and p53 in the osteoblast lineage. Proc Natl Acad Sci. 2008;105(33):11851-6.

63. Chen X, Bahrami A, Pappo A, Easton J, Dalton J, Hedlund E, Parker M. Recurrent somatic structural variations contribute to tumorigenesis in pediatric osteosarcoma. Cell Rep. 2014;7(1):104-12.

64. Savage SA, Mirabello L, Wang Z, Gastier-Foster JM, Gorlick R, Khanna C, Gokgoz N. Genome-wide association study identifies two susceptibility loci for osteosarcoma. Nat Genet. 2013;45(7):799-803.
65. Onda M, Matsuda S, Higaki S, Iijima T, Fukushima JI, Yokokura A, Yamamoto T. ErbB-2 expression is correlated with poor prognosis for patients with osteosarcoma. Cancer. 1996;77(1):71-8.

66. Akatsuka T, Wada T, Kokai Y, Kawaguchi S, Isu K, Yamashiro K, Ishii S. ErbB2 expression is correlated with increased survival of patients with osteosarcoma. Cancer. 2002;94(5):1397-404.

67. Gemoll T, Epping F, Heinrich L, Fritzsche B, Roblick UJ, Szymczak S, Lehr S. Increased cathepsin D protein expression is a biomarker for osteosarcomas, pulmonary metastases and other bone malignancies. Oncotarget. 2015;6(18):16517.

68. Li Z, Xiao J, Hu K, Wang G, Li M, Zhang J, Cheng G. FBXW7 acts as an independent prognostic marker and inhibits tumor growth in human osteosarcoma. Int J Mol Sci. 2015;16(2):2294-306.

69. Zhou S, Wang B, Hu J, Zhou Y, Jiang M, Wu M, Yang $\mathrm{X}$. miR-421 is a diagnostic and prognostic marker in patients with osteosarcoma. Tumor Biol. 2016;37:9001-7.

70. He J, Zhang P, Li Q, Zhou D, Liu P. Expression of high mobility group box 1 protein predicts a poorer prognosis for patients with osteosarcoma. Oncol Lett. 2016;11(1):293-8.

71. Zandueta C, Ormazábal C, Perurena N, MartínezCanarias S, Zalacaín M, San Julián M, Vicent S. Matrix-Gla protein promotes osteosarcoma lung metastasis and associates with poor prognosis. J Pathol. 2016; 239(4):438-9.

72. Smeland S, Müller C, Alvegard TA, Wiklund T, Wiebe T, Björk O, Brosjö O. Scandinavian Sarcoma Group Osteosarcoma Study. SSG VIII: prognostic factors for outcome and the role of replacement salvage chemotherapy for poor histological responders. Eur J Cancer. 2003;39(4):488-94.

73. Pakos EE, Nearchou AD, Grimer RJ, Koumoullis HD, Abudu A, Bramer JA, Capanna R. Prognostic factors and outcomes for osteosarcoma: an international collaboration. Eur J Cancer. 2009;45(13):2367-75.

74. Harting MT, Lally KP, Andrassy RJ, Vaporciyan AA, Cox CS Jr, Hayes-Jordan A, Blakely ML. Age as a prognostic factor for patients with osteosarcoma: an analysis of 438 patients. J Cancer Res Clin Oncol. 2010;136(4):561-70.

75. Longhi A, Pasini A, Cicognani A, Baronio F, Pellacani A, Baldini N, Bacci G. Height as a risk factor for osteosarcoma. J Pediatr Hematol Oncol. $2005 ; 27(6): 314-8$.

76. Pui CH, Boyett JM, Hancock ML, Pratt CB, Meyer WH, Crist WM. Outcome of treatment for 
childhood cancer in black as compared with white children: the St Jude Children's Research Hospital experience, 1962 through 1992. JAMA. 1995;273(8):633-7.

77. Ru G, Terracini B, Glickman LT. Host related risk factors for canine osteosarcoma. Vet J. 1998;156(1):31-9.

78. Gelberg KH, Fitzgerald EF, Hwang S, Dubrow R. Growth and development and other risk factors for osteosarcoma in children and young adults. Int J Epidemiol. 1997;26(2):272-8.

79. Ruza E, Sotillo E, Sierrasesúmaga L, Azcona C, Patiño-García A. Analysis of polymorphisms of the vitamin D receptor, estrogen receptor, and collagen I $\alpha 1$ genes and their relationship with height in children with bone cancer. J Pediatr Hematol Oncol. 2003;25(10):780-6.

80. Arora RS, Kontopantelis E, Alston RD, Eden TO, Geraci M, Birch JM. Relationship between height at diagnosis and bone tumours in young people: a meta-analysis. Cancer Causes Control. 2011;22(5):681-8.

81. Buckley JD, Pendergrass TW, Buckley CM, Pritchard DJ, Nesbit ME, Provisor AJ, Robison LL. Epidemiology of osteosarcoma and Ewing's sarcoma in childhood. Cancer. 1998;83(7):1440-8.

82. Subbiah V, Madsen VS, Raymond AK, Benjamin RS, Ludwig JA. Of mice and men: divergent risks of teriparatide-induced osteosarcoma. Osteoporos Int. 2010;21(6):1041-5.

83. Bassin EB, Wypij D, Davis RB, Mittleman MA. Age-specific fluoride exposure in drinking water and osteosarcoma (United States). Cancer Causes Control. 2006;17(4):421-8.

84. Gandhi D, Naoghare PK, Bafana A, Kannan K, Sivanesan S. Fluoride-induced oxidative and inflammatory stress in osteosarcoma cells: does it affect bone development pathway? Biol Trace Elem Res. 2016, 1-9.

85. Andrews EB, Gilsenan AW, Midkiff K, Sherrill B, Wu $\mathrm{Y}$, Mann BH, Masica D. The US postmarketing surveillance study of adult osteosarcoma and teriparatide: study design and findings from the first 7 years. J Bone Miner Res. 2012;27(12):2429-37.

86. Kim FM, Hayes C, Williams PL, Whitford GM, Joshipura KJ, Hoover RN, Eckardt JJ. An assessment of bone fluoride and osteosarcoma. J Dent Res. 2011;90(10):1171-6.

87. Archer NP, Napier TS, Villanacci JF. Fluoride exposure in public drinking water and childhood and adolescent osteosarcoma in Texas. Cancer Causes Control. 2016, 1-6.

88. Levy M, Leclerc BS. Fluoride in drinking water and osteosarcoma incidence rates in the continental United States among children and adolescents. Cancer Epidemiol. 2012;36(2):e83-8.

89. Wittig JC, Bickels J, Priebat D, Jelinek J, Kellar-Graney K, Shmookler B, Malawer MM. Osteosarcoma: a multidisciplinary approach to diagnosis and treatment. Am Fam Phys. 2002;65(6).

90. Widhe $\mathrm{B}$, Widhe $\mathrm{T}$. Initial symptoms and clinical features in osteosarcoma and Ewing sarcoma. J Bone Joint Surg. 2000;82(5):667-74.

91. Pan KL, Chan WH, Chia YY. Initial symptoms and delayed diagnosis of osteosarcoma around the knee joint. J Orthop Surg. 2010;18(1):55.

92. Wick MR, McLeod RA, Siegal GP, Greditzer HG III, Unni KK. Sarcomas of bone complicating osteitis deformans (Paget's disease): fifty years' experience. Am J Surg Pathol. 1981;5(1):47-60.

93. Grimer RJ, Cannon SR, Taminiau AM, Bielack S, Kempf-Bielack B, Windhager R, Szendroi M. Osteosarcoma over the age of forty. Eur J Cancer. 2003;39(2):157-63.

94. Liu PPL, Leung KS, Kumta SM, Lee KM, Fung KP. Bone-specific alkaline phosphatase in plasma as tumour marker for osteosarcoma. Oncology. 1996;53(4):275-80.

95. Limmahakhun S, Pothacharoen P, Theera-Umpon $\mathrm{N}$, Arpornchayanon $\mathrm{O}$, Leerapun $\mathrm{T}$, Luevitoonvechkij S, Pruksakorn D. Relationships between serum biomarker levels and clinical presentation of human osteosarcomas. Asian Pac J Cancer Prev. 2011;12(7):1717-22.

96. Bieling P, Rehan N, Winkler P, Helmke K, Maas R, Fuchs N, Romanowski R. Tumor size and prognosis in aggressively treated osteosarcoma. J Clin Oncol. 1996;14(3):848-58.

97. Geller DS, Gorlick R. Osteosarcoma: a review of diagnosis, management, and treatment strategies. Clin Adv Hematol Oncol. 2010;8(10):705-18.

98. Stokkel M, Linthorst M, Borm J, Taminiau A, Pauwels E. A reassessment of bone scintigraphy and commonly tested pretreatment biochemical parameters in newly diagnosed osteosarcoma. J Cancer Res Clin Oncol. 2002;128(7):393-9.

99. Bone Cancer-NCCN. (n.d.). Retrieved November 3, 2016, from http://www.nccn.org/professionals/ physician_gls/PDF/bone.pdf. 
100. Costelloe CM, Macapinlac HA, Madewell JE, Fitzgerald NE, Mawlawi OR, Rohren EM, Harrell RK. 18F-FDG PET/CT as an indicator of progression-free and overall survival in osteosarcoma. J Nucl Med. 2009;50(3):340-7.

101. Hurley C, McCarville MB, Shulkin BL, Mao S, Wu J, Navid F, Bishop MW. Comparison of 18F-FDGPET-CT and bone scintigraphy for evaluation of osseous metastases in newly diagnosed and recurrent osteosarcoma. Pediatr Blood Cancer. 2016.

102. Im HJ, Wu H, Yi Z, Wu J, Shulkin B, Cho S. Baseline metabolic tumor volume measured by FDG PET/CT before neoadjuvant chemotherapy predicts survival in pediatric osteosarcoma. J Nucl Med. 2016;57(supplement 2):429.

103. Bajpai J, Kumar R, Sreenivas V, Sharma MC, Khan SA, Rastogi S, Bakhshi S. Prediction of chemotherapy response by PET-CT in osteosarcoma: correlation with histologic necrosis. J Pediatr Hematol Oncol. 2011;33(7):e271-8.

104. Huvos AG, Rosen GERALD, Marcove RC. Primary osteogenic sarcoma: pathologic aspects in 20 patients after treatment with chemotherapy en bloc resection, and prosthetic bone replacement. Arch Pathol Lab Med. 1977;101(1):14-8.

105. Picci P. Osteosarcoma (osteogenic sarcoma). Orphanet J Rare Dis. 2007;2(1):1.

106. Murphey MD, Robbin MR, MCRae GA, Flemming DJ, Temple HT, Kransdorf MJ. The many faces of osteosarcoma. Radiographics. 1997;17(5):1205-31.

107. Bacci G, Bertoni F, Longhi A, Ferrari S, Forni C, Biagini R, Lari S. Neoadjuvant chemotherapy for high-grade central osteosarcoma of the extremity. Cancer. 2003;97(12):3068-75.

108. Enneking WF, Spanier SS, Goodman MA. A system for the surgical staging of musculoskeletal sarcoma. Clin Orthop Relat Res. 1980;153:106-20.

109. American Cancer Society| Information and Resources for Cancer: Breast, Colon, Lung, Prostate, Skin. (n.d.). Retrieved July 15, 2016, from http://www.cancer.org/.

110. AJCC-American Joint Committee on Cancer. (n.d.). Retrieved July 15, 2016, from https:// cancerstaging.org/Pages/default.aspx.

111. Osteosarcoma. (n.d.). Retrieved July 25, 2016, from http://www.cancer.org/cancer/osteosarcoma/index.

112. Menendez LR. OKU, orthopaedic knowledge update. Rosemont: American Academy of Orthopaedic Surgeons; 2002.
113. Kudawara I, Aoki $\mathrm{Y}$, Ueda T, Araki N, Naka N, Nakanishi H, Kuratsu S. Neoadjuvant and adjuvant chemotherapy with high-dose ifosfamide, doxorubicin, cisplatin and high-dose methotrexate in non-metastatic osteosarcoma of the extremities: a phase II trial in Japan. J Chemother. 2013;25(1):41-8.

114. Bramwell VH, Burgers M, Sneath RSEA, Souhami R, van Oosterom AT, Voute PA, Somers R. A comparison of two short intensive adjuvant chemotherapy regimens in operable osteosarcoma of limbs in children and young adults: the first study of the European Osteosarcoma Intergroup. J Clin Oncol. 1992;10(10):1579-91.

115. Anninga JK, Gelderblom H, Fiocco M, Kroep JR, Taminiau AH, Hogendoorn PC, Egeler RM. Chemotherapeutic adjuvant treatment for osteosarcoma: where do we stand? Eur J Cancer. 2011;47(16):2431-45.

116. Ferrari S, Smeland S, Mercuri M, Bertoni F, Longhi A, Ruggieri P, Müller C. Neoadjuvant chemotherapy with high-dose Ifosfamide, high-dose methotrexate, cisplatin, and doxorubicin for patients with localized osteosarcoma of the extremity: a joint study by the Italian and Scandinavian Sarcoma Groups. J Clin Oncol. 2005;23(34):8845-52.

117. Ferrari S, Ruggieri P, Cefalo G, Tamburini A, Capanna R, Fagioli F, Alberghini M. Neoadjuvant chemotherapy with methotrexate, cisplatin, and doxorubicin with or without ifosfamide in nonmetastatic osteosarcoma of the extremity: an Italian sarcoma group trial ISG/OS-1. J Clin Oncol JCO 2011. 2012.

118. Marina N, Smeland S, Bielack S, et al. Comparison of MAPIE versus MAP in patients with a poor response to pre-operative chemotherapy for newly diagnosed high-grade osteosarcoma (EURAMOS-1): an open-label, international, randomized, phase 3, controlled trial. Lancet Oncol. 2016;17(10): 1396-408.

119. Eilber FR, Rosen G. Adjuvant chemotherapy for osteosarcoma. Semin Oncol. 1989;16(4):312-22.

120. Link MP, Goorin AM, Miser AW, Green AA, Pratt CB, Belasco JB, Ayala AG. The effect of adjuvant chemotherapy on relapse-free survival in patients with osteosarcoma of the extremity. N Engl J Med. 1986;314(25):1600-6.

121. Picci P, Bacci G, Campanacci M, Gasparini M, Pilotti S, Cerasoli S, Galletti S. Histologic evaluation of necrosis in osteosarcoma induced by chemotherapy regional mapping of viable and nonviable tumor. Cancer. 1985;56(7):1515-21.

122. Marina N, Smeland S, Bielack SS, Bernstein M, Jovic G, Hook JM, Teot L. MAPIE vs MAP as postoperative 
chemotherapy in patients with a poor response to preoperative chemotherapy for newly-diagnosed osteosarcoma: results from EURAMOS-1 (Paper 032). 2014.

123. Bertrand TE, Cruz A, Binitie O, Cheong D, Letson GD. Do surgical margins affect local recurrence and survival in extremity, nonmetastatic, high-grade osteosarcoma? Clin Orthop Relat Res ${ }^{\circledR}$. 2016;474(3):677-83.

124. Li X, Moretti VM, Ashana AO, Lackman RD. Impact of close surgical margin on local recurrence and survival in osteosarcoma. Int Orthop. 2012;36(1):131-7.

125. Jeon DG, Song WS, Kong CB, Cho WH, Cho SH, Lee JD, Lee SY. Role of surgical margin on local recurrence in high risk extremity osteosarcoma: a case-controlled study. Clin Orthop Surg. 2013;5(3):216-24.

126. Bacci G, Ferrari S, Mercuri M, Bertoni F, Picci P, Manfrini M, Campanacci M. Predictive factors for local recurrence in Osteosarcoma 540 patients with extremity tumors followed for minimum 2.5 years after neoadjuvant chemotherapy. Acta Orthop Scand. 1998;69(3):230-6.

127. Rougraff BT, Simon MA, Kneisl JS, Greenberg DB, Mankin HJ. Limb Salvage compared with amputation for osteosarcoma of the distal end of the femur: a long-term oncological, functional, and quality-of-life study. J Bone Joint Surg Am. 1994;76(5):649-56.

128. Springfield DS, Schmidt RICHARD, Graham-Pole JOHN, Marcus RB, Spanier SS, Enneking WF. Surgical treatment for osteosarcoma. J Bone Joint Surg Am. 1988;70(8):1124-30.

129. Abudu A, Sferopoulos NK, Tillman RM, Carter SR, Grimer RJ. The surgical treatment and outcome of pathological fractures in localised osteosarcoma. Bone Joint J. 1996;78(5):694-8.

130. Simon MA, Aschliman MA, Thomas N, Mankin HJ. Limb-salvage treatment versus amputation for osteosarcoma of the distal end of the femur. J Bone Joint Surg Am. 1986;68(9):1331-7.

131. Redondo A, Cruz J, Lopez-Pousa A, Barón F. SEOM clinical guidelines for the treatment of osteosarcoma in adults-2013. Clin Transl Oncol. 2013;15(12):1037-43.

132. Saeter G, Høie J, Stenwig AE, Johansson AK, Hannisdal E, Solheim ØР. Systemic relapse of patients with osteogenic sarcoma. Prognostic factors for long-term survival. Cancer. 1995;75(5):1084-93.
133. Bacci G, Mercuri M, Briccoli A, Ferrari S, Bertoni F, Donati D, Manfrini M. Osteogenic sarcoma of the extremity with detectable lung metastases at presentation. Cancer. 1997;79(2):245-54.

134. Briccoli A, Rocca M, Salone M, Bacci G, Ferrari S, Balladelli A, Mercuri M. Resection of recurrent pulmonary metastases in patients with osteosarcoma. Cancer. 2005;104(8):1721-5.

135. Tabone MD, Kalifa C, Rodary C, Raquin M, Valteau-Couanet D, Lemerle J. Osteosarcoma recurrences in pediatric patients previously treated with intensive chemotherapy. J Clin Oncol. 1994;12(12):2614-20.

136. Chou AJ, Merola PR, Wexler LH, Gorlick RG, Vyas $\mathrm{YM}$, Healey JH, Meyers PA. Treatment of osteosarcoma at first recurrence after contemporary therapy. Cancer. 2005;104(10): 2214-21.

137. McTiernan A, Meyer T, Michelagnoli MP, Lewis I, Whelan JS. A phase I/II study of doxorubicin, ifosfamide, etoposide and interval methotrexate in patients with poor prognosis osteosarcoma. Pediatr Blood Cancer. 2006;46(3):345-50.

138. DeLaney TF, Park L, Goldberg SI, Hug EB, Liebsch NJ, Munzenrider JE, Suit HD. Radiotherapy for local control of osteosarcoma. Int J Radiat Oncol* ${ }^{*}$ Biol $^{*}$ Phys. 2005;61(2):492-8.

139. Longhi A, Errani C, De Paolis M, Mercuri M, Bacci G. Primary bone osteosarcoma in the pediatric age: state of the art. Cancer Treat Rev. 2006;32(6):423-36.

140. Marina N, Gebhardt M, Teot L, Gorlick R. Biology and therapeutic advances for pediatric osteosarcoma. Oncologist. 2004;9(4):422-41.

141. Zhou H, Randall RL, Brothman AR, Maxwell T, Coffin CM, Goldsby RE. Her-2/neu expression in osteosarcoma increases risk of lung metastasis and can be associated with gene amplification. J Pediatr Hematol Oncol. 2003;25(1):27-32.

142. Ebb D, Meyers P, Grier H, Bernstein M, Gorlick R, Lipshultz SE, Ferguson WS. Phase II trial of trastuzumab in combination with cytotoxic chemotherapy for treatment of metastatic osteosarcoma with human epidermal growth factor receptor 2 overexpression: a report from the Children's Oncology Group. J Clin Oncol. 2012;30(20):2545-51.

143. Bell RS. Expression of insulin-like growth factor receptor, IGF-1, and IGF-2 in primary and metastatic osteosarcoma. J Surg Oncol. 1998;69:21-7. 
144. Pappo AS, Vassal G, Crowley JJ, Bolejack V, Hogendoorn PC, Chugh R, Chawla SP. A phase 2 trial of R1507, a monoclonal antibody to the insulin-like growth factor-1 receptor (IGF-1R), in patients with recurrent or refractory rhabdomyosarcoma, osteosarcoma, synovial sarcoma, and other soft tissue sarcomas: results of a Sarcoma Alliance for Research Through Collaboration study. Cancer. 2014;120(16):2448-56.

145. Perry JA, Kiezun A, Tonzi P, Van Allen EM, Carter SL, Baca SC, Helman E. Complementary genomic approaches highlight the PI3K/mTOR pathway as a common vulnerability in osteosarcoma. Proc Natl Acad Sci. 2014;111(51):E5564-73.

146. Moriarity BS, Otto GM, Rahrmann EP, Rathe SK, Wolf NK, Weg MT, Choi K. A Sleeping Beauty forward genetic screen identifies new genes and pathways driving osteosarcoma development and metastasis. Nat Genet. 2015;47(6):615-24.

147. Grignani G, Palmerini E, Dileo P, Asaftei SD, D’Ambrosio L, Pignochino Y, Ferrari S. A phase II trial of sorafenib in relapsed and unresectable high-grade osteosarcoma after failure of standard multimodal therapy: an Italian Sarcoma Group study. Ann Oncol, mdr151. 2011.

148. Sulzbacher I, Birner P, Trieb K, Träxler M, Lang S, Chott A. Expression of platelet-derived growth factor-AA is associated with tumor progression in osteosarcoma. Mod Pathol. 2003;16(1):66-71.

149. Nash GF, Turner LF, Scully MF, Kakkar AK. Platelets and cancer. Lancet Oncol. 2002;3(7):425-30.

150. Labelle M, Begum S, Hynes RO. Direct signaling between platelets and cancer cells induces an epithelial-mesenchymal-like transition and promotes metastasis. Cancer Cell. 2011;20(5):576-90.

151. Takagi S, Takemoto A, Takami M, Oh-hara T, Fujita N. Platelets promote osteosarcoma cell growth through activation of the platelet-derived growth factor receptor-Akt signaling axis. Cancer Sci. 2014;105(8):983-8.

152. Kumar RMR, Arlt MJ, Kuzmanov A, Born W, Fuchs B. Sunitinib malate (SU-11248) reduces tumour burden and lung metastasis in an intratibial human xenograft osteosarcoma mouse model. Am J Cancer Res. 2015;5(7):2156.

153. Huang J, Liu K, Yu Y, Xie M, Kang R, Vernon PJ, Ni J. Targeting HMGB1-mediated autophagy as a novel therapeutic strategy for osteosarcoma. Autophagy. 2012.

154. Ouyang Z, Li H, Zhai Z, Xu J, Dass CR, Qin A, Dai K. Zoledronic acid: pleiotropic anti-tumor mechanism and therapeutic outlook for osteosarcoma. Curr Drug Targets. 2015.

155. Chang R, Sun L, Webster TJ. Short communication: selective cytotoxicity of curcumin on osteosarcoma cells compared to healthy osteoblasts. Int J Nanomed. 2014;9:461-5.

156. Mori K, Rédini F, Gouin F, Cherrier B, Heymann D. Osteosarcoma: current status of immunotherapy and future trends (Review). Oncol Rep. 2006;15(3):693-700.

157. Wan J, Zhang X, Liu T, Zhang X. Strategies and developments of immunotherapies in osteosarcoma (Review). Oncol Lett. 2016;11(1):511-20.

158. Ortega RA, Barham W, Kumar B, Shann SY, Yull F, Giorgio TD. Reprogramming tumor associated macrophages toward an anti-tumor phenotype by targeting the NF- $\mathrm{B}$ pathway using novel targeted nanotherapeutics. Cancer Res. 2013;73(8 Supplement):3981.

159. Kleinerman ES, Jia SF, Griffin J, Seibel NL, Benjamin RS, Jaffe N. Phase II study of liposomal muramyl tripeptide in osteosarcoma: the cytokine cascade and monocyte activation following administration. J Clin Oncol. 1992;10(8):1310-6.

160. Meyers PA, Chou AJ. Muramyl tripeptide-phosphatidyl ethanolamine encapsulated in liposomes (L-MTP-PE) in the treatment of osteosarcoma. In: Current advances in osteosarcoma. Springer International Publishing; 2014. p. 307-21.

161. Lammers TGGM, Hennink WE, Storm G. Tumour-targeted nanomedicines: principles and practice. Br J Cancer. 2008;99(3):392-7.

162. Fang J. Nano-or submicron-sized liposomes as carriers for drug delivery. Chang Gung Med J. 2006;29(4):358-62.

163. Kleinerman ES, Erickson KL, Schroit AJ, Fogler WE, Fidler IJ. Activation of tumoricidal properties in human blood monocytes by liposomes containing lipophilic muramyl tripeptide. Cancer Res. 1983;43(5):2010-4.

164. Mantovani A, Sozzani S, Locati M, Allavena P, Sica A. Macrophage polarization: tumor-associated macrophages as a paradigm for polarized M2 mononuclear phagocytes. Trends Immunol. 2002;23(11):549-55.

165. Buddingh EP, Kuijjer ML, Duim RA, Bürger $H$, Agelopoulos K, Myklebost O, Cleton-Jansen AM. Tumor-infiltrating macrophages are associated with metastasis suppression in high-grade osteosarcoma: a rationale for treatment with macrophage 
activating agents. Clin Cancer Res. 2011;17(8):2110-9.

166. Meyers PA, Schwartz CL, Krailo MD, Healey JH, Bernstein ML, Betcher D, Kleinerman E. Osteosarcoma: the addition of muramyl tripeptide to chemotherapy improves overall survival-a report from the Children's Oncology Group. J Clin Oncol. 2008;26(4):633-8.

167. Chou AJ, Kleinerman ES, Krailo MD, Chen Z, Betcher DL, Healey JH, Womer RB. Addition of muramyl tripeptide to chemotherapy for patients with newly diagnosed metastatic osteosarcoma. Cancer. 2009;115(22):5339-48.

168. Biteau K, Guiho R, Chatelais M, Taurelle J, Chesneau J, Corradini N, Redini F. L-MTP-PE and zoledronic acid combination in osteosarcoma: preclinical evidence of positive therapeutic combination for clinical transfer. Am J Cancer Res. 2016;6(3):677.

169. Jia SF, Worth LL, Densmore CL, Xu B, Duan X, Kleinerman ES. Aerosol gene therapy with PEI IL-12 eradicates osteosarcoma lung metastases. Clin Cancer Res. 2003;9(9):3462-8.

170. Strauss SJ, McTiernan A, Whelan JS. Late relapse of osteosarcoma: implications for follow-up and screening. Pediatr Blood Cancer. 2004;43(6):692-7.

171. Chi SN, Conklin LS, Qin J, Meyers PA, Huvos AG, Healey JH, Gorlick R. The patterns of relapse in osteosarcoma: the memorial Sloan-Kettering experience. Pediatr Blood Cancer. 2004;42(1):46-51.

172. Hamilton JA. GM-CSF in inflammation and autoimmunity. Trends Immunol. 2002;23(8):403-8.

173. Arndt CA, Koshkina NV, Inwards CY, Hawkins DS, Krailo MD, Villaluna D, Bell SA. Inhaled GM-CSF for first pulmonary recurrence of osteosarcoma; effects on disease free survival and immunomodulation: a report from the Children's Oncology Group. Clin Cancer Res Off J Am Assoc Cancer Res. 2010;16(15):4024.

174. Wilson J, Balkwill F. The role of cytokines in the epithelial cancer microenvironment. In: Seminars in cancer biology, vol. 12, no. 2. Academic Press; 2002. p. 113-120.

175. Dranoff G. Cytokines in cancer pathogenesis and cancer therapy. Nat Rev Cancer. 2004;4(1):11-22.

176. Lasfar A, Abushahba W, Balan M, Cohen-Solal KA. Interferon lambda: a new sword in cancer immunotherapy. Clin Develop Immunol. 2011;2011:349575.
177. Zeidner JF, Gladstone DE, Zahurak M, Matsui WH, Gocke C, Jones RJ, Smith BD. Granulocyte-macrophage colony stimulating factor (GM-CSF) enhances the clinical responses to interferon- $\alpha$ (IFN) in newly diagnosed chronic myeloid leukemia (CML). Leuk Res. 2014;38(8): 886-90.

178. Wang Z, Qiu SJ, Ye SL, Tang ZY, Xiao X. Combined IL-12 and GM-CSF gene therapy for murine hepatocellular carcinoma. Cancer Gene Therapy. 2001;8(10):751-8.

179. Guma SR, Lee DA, Yu L, Gordon N, Hughes D, Stewart J, Kleinerman ES. Natural killer cell therapy and aerosol interleukin-2 for the treatment of osteosarcoma lung metastasis. Pediatr Blood Cancer. 2014;61(4):618-26.

180. Buddingh EP, Schilham MW, Ruslan SEN, Berghuis D, Szuhai K, Suurmond J, Hogendoorn PC. Chemotherapy-resistant osteosarcoma is highly susceptible to IL-15-activated allogeneic and autologous NK cells. Cancer Immunol Immunother. 2011;60(4):575-86.

181. Worth LL, Jia SF, Zhou Z, Chen L, Kleinerman ES. Intranasal therapy with an adenoviral vector containing the murine interleukin-12 gene eradicates osteosarcoma lung metastases. Clin Cancer Res. 2000;6(9):3713-8.

182. Belardelli F, Ferrantini M, Proietti E, Kirkwood JM. Interferon-alpha in tumor immunity and immunotherapy. Cytokine Growth Factor Rev. $2002 ; 13(2): 119-34$.

183. Zhao J, Wang M, Li Z, Chen J, Yin Z, Chang J, Wang $S$. Interferon- $\alpha$ suppresses invasion and enhances cisplatin-mediated apoptosis and autophagy in human osteosarcoma cells. Oncol Lett. 2014;7(3):827-33.

184. Bielack SS, Smeland S, Whelan JS, Marina N, Jovic G, Hook JM, Nadel H. Methotrexate, doxorubicin, and cisplatin (MAP) plus maintenance pegylated interferon alfa- $2 \mathrm{~b}$ versus MAP alone in patients with resectable high-grade osteosarcoma and good histologic response to preoperative MAP: first results of the EURAMOS-1 good response randomized controlled trial. J Clin Oncol. 2015;33(20):2279-87.

185. Uzé G, Monneron D. IL-28 and IL-29: newcomers to the interferon family. Biochimie. 2007;89(6): 729-34.

186. Gao D, Zhao J, Li X, Xia Y, Cai Y, Pan J, Wen H. Interferon- $\lambda 1$ suppresses invasion and enhances autophagy in human osteosarcoma cell. Int J Clin Exp Med. 2015;8(9):14999. 
187. Li Z, Tang J, Ye Z. Interferon- $\gamma$ enhances human $\gamma \delta \mathrm{T}$ cell-mediated osteosarcoma cell killing in vitro. Nan fang yi ke da xue xue bao J South Med Univ. 2013;33(1):22.

188. Zou W. Immunosuppressive networks in the tumour environment and their therapeutic relevance. Nat Rev Cancer. 2005;5(4):263-74.

189. Francisco LM, Salinas VH, Brown KE, Vanguri VK, Freeman GJ, Kuchroo VK, Sharpe AH. PD-L1 regulates the development, maintenance, and function of induced regulatory T cells. J Exp Med. 2009;206(13):3015-29.

190. Tivol EA, Borriello F, Schweitzer AN, Lynch WP, Bluestone JA, Sharpe AH. Loss of CTLA-4 leads to massive lymphoproliferation and fatal multiorgan tissue destruction, revealing a critical negative regulatory role of CTLA-4. Immunity. 1995;3(5):541-7.

191. Parry RV, Chemnitz JM, Frauwirth KA, Lanfranco AR, Braunstein I, Kobayashi SV, Riley JL. CTLA-4 and PD-1 receptors inhibit T-cell activation by distinct mechanisms. Mol Cell Biol. 2005;25(21):9543-53.

192. Grosso JF, Jure-Kunkel MN. CTLA-4 blockade in tumor models: an overview of preclinical and translational research. Cancer Immunity Arch. 2013;13(1):5.
193. Lussier DM, Johnson JL, Hingorani P, Blattman JN. Abstract A07: combining CTLA4 and PD-L1 blockade leads to complete eradication of metastatic osteosarcoma. Cancer Immunol Res. 2015;3(10 Supplement):A07.

194. Lussier DM, Johnson JL, Hingorani P, Blattman JN. Combination immunotherapy with $\alpha$-CTLA- 4 and $\alpha$-PD-L1 antibody blockade prevents immune escape and leads to complete control of metastatic osteosarcoma. J Immunother Cancer. 2015;3(1):1.

195. Franzius C, Daldrup-Link HE, Sciuk J, Rummeny EJ, Bielack S, Jürgens $H$, Schober $O$. FDG-PET for detection of pulmonary metastases from malignant primary bone tumors: comparison with spiral CT. Ann Oncol. 2001;12(4):479-86.

196. Byun BH, Kong CB, Lim I, Kim BI, Choi CW, Song WS, Lim SM. Comparison of (18) F-FDG PET/CT and (99 m) Tc-MDP bone scintigraphy for detection of bone metastasis in osteosarcoma. Skeletal Radiol. 2013;42(12):1673-81.

197. Charest M, Hickeson M, Lisbona R, Novales-Diaz JA, Derbekyan V, Turcotte RE. FDG PET/CT imaging in primary osseous and soft tissue sarcomas: a retrospective review of 212 cases. Eur J Nucl Med Mol Imaging. 2009;36(12):1944-51. 